\author{
С.Г. Сукиасян
}

\title{
СТРАТЕГИИ ПОВЕДЕНИЯ ЧЕЛОВЕКА: АНИМИСТИЧЕСКИЕ И АНТРОПОМОРФНЫЕ КОРНИ
}

\begin{abstract}
Аннотация. Предмет настоящего исследования является категория "стратегия поведения» как аспект понимания природы и психики человека в контексте их возникновения и развития. Автором проведён анализ наиболее известных, эволючионно значимых стратегий поведения человека, так или иначе объясняющих формы поведения человека. Многообразие этих стратегий автор рассматривает как некий континуум, обусловленный взаимодействием и взаимовлиянием биологической и сочиальной природы человека. При этом автор не сводит социальное в человеке к его биологии, но выводит социальное в человеке исключительно из его биологии. Для понимания разрабатываемой концепции развития психики автор обратился к понятию "эволюционно стабильная стратегия поведения", которую развивали психобиологи. Работа теоретическая и основана на анализе категориальных понятий и подходов, принятых в психологии и психиатрии. В статье представлен оригинальный подход автора к пониманию природы и психики человека. При этом автор исходит из того, что суть любого человеческого феномена проявляется в его крайностях, в данном случае в психозах. Многообразие форм поведения человека сводится к следующим четырём типам: агонистическое, кооперативное, альтруистическое и эгоистическое. Представлен анализ каждой из форм поведенческих стратегий. Автор предполагает, что понять человека, его природу можно через понимание его социального поведения, которое он рассматривает под углом зрения группового и общественного поведения животных, проводя аналогии в моделях животного и человеческого поведения. Раскрыта эволючионная роль некоторых психологических категорий. Автор развивает идею антропоморфизации животных и анимализации человека. Становление вида Hото Sapiens осуществляется через его инстинктивную природу, опосредованную социальными отношениями и взаимодействием с внешними факторами. Автор предполагает, что на современном этапе своего развития человек утратил ряд биологических механизмов регулирования генетической структуры популяции, заменив их социальными механизмами: институтами, выполняющими запретительные, карательные функции в виде моральных норм, законов, уголовного кодекса. Иными словами иерархически более старый механизм (или пласт) уступил место более новому механизму, но, при этом, он сохранился в "неактивном состоянии». Психические феномены, социальные и моральные нормы и принципы, законы, регулирующие общественную жизнь в своём глубинном значении, являются диктатом биологической и физической (косной) природы.
\end{abstract}

Ключевые слова: стратегии поведения, агонистическое поведение, кооперативное поведение, альтруистическое поведение, эгоистическое поведение, закрытая генетическая программа, открытая поведенческая программа, внешняя программа, анимализация человека, антропоморфизация животных.

Abstract. The subject of the present study is the category "strategy» as an aspect of understanding the nature and the human psyche in the context of their origins and development. The author of the analysis of the most famous, evolutionarily significant strategies of human behavior, in one way or another to explain human behaviour. The diversity of these strategies the author considers as a continuum, caused by the interaction and the interaction between biological and social nature of man. The author does not reduce social in person to its biology, but displays a social in man solely from his biology. For understanding the evolving concept of development of the psyche, the author appealed to the notion of «evolutionarily stable strategy, which developed psihobiologi. The diversity of forms of human behaviour is reduced to the following four types: agonistic, cooperative, altruistic and egoistic. An analysis of each of the forms of behavioral strategies. Work is theoretical and based on an analysis of categorical concepts and approaches in psychology and Psychiatry. The article presents the author's original approach to understanding the nature and the human psyche. If this comes from the fact that the essence of any human phenomenon is manifested in its extremes. In this case the psychosis. The author suggests that to understand human nature can be via understanding his social behavior, which he views from the perspective of group and social behaviour of animals, conducting similar in models of animal and human behavior. Disclosed to the evolutionary role of some psychological categories. The author develops the idea of animal and human animistic antropomorfic. The formation of the species Homo Sapiens is 


\section{Философия и психология}

carried out through his instinctive nature, indirect social relations and interactions with external factors. The author assumes that at the present stage of its development, man lost several biological mechanisms for the management of population genetic structure, replacing them with social mechanisms: institutions that perform prohibitive, punitive function as moral norms, laws, Penal Code. In other words a hierarchically more old mechanism (or seam) gave way to more new mechanism, but at the same time, he remained in «inactive». Psychic manifestations, social and moral norms and principles, laws regulating social life in its deepest meaning are the dictates of biological and physical nature.

Key words: animalization human, external program, behavior strategy, agonistic behavior, cooperative behavior, altruistic behavior, selfish behavior, closed genetic program, open behavioral program, anthropomorphization of animals.

$\mathrm{K}$ то и что есть Человек? Клубок животных инстинктов, приобретённых рефлексов или вселенский (божественный) «кибернетический аппарат»? Он порождение социальной среды или эволюционный продукт его биологической природы? Он есть дитя Бога или плод инопланетного эксперимента? Что делает человека человеком? Его страхи? мысли? сознание? креативность? мораль? разум? Это вопросы, которыми задаётся любой человек, независимо от образования, специальности, пола или возраста. Причём вопросы эти возникают ещё на заре жизни, с детства, а с возрастом приобретают другой смысл и другое содержание. Найти ответы на эти вопросы пытаются наши пациенты, задаваясь вопросом о том, стоит ли жизнь тех страданий, которые достались им. Особо актуально звучат они в экстремальных ситуациях или в состояниях психологического кризиса. Вопросы и ответы отягощаются жизненным опытом, знаниями. И всё равно, эти вопросы остаются чаще всего без ответа. Это темы, которые относятся к фундаментальным вопросам психологии. И на них пытались отвечать такие известные исследователи, как З. Фрейд, К. Юнг, Э. Фромм, В. Франкл, К. Хорни, А. Маслоу и другие. Каждый был прав по своему, и каждый точно так же заблуждался.

Естественно, что подобные вопросы возникали и у меня, и каждый раз с определённым возрастным оттенком. Но как-то смелости не хватало говорить о них вслух. То ли нерешительность, то ли не готовность... Отсутствие ответа на эти вопросы вызывает у меня беспокойство, как в профессиональном плане, так и в бытовом. В отличие от некоторых вышеперечисленных авторов жизнь у меня протекала нормально - были драмы, но не было трагедий, болезней. Не было страхов и фрустраций, которые надо было перебороть. Мне не с кем было противопоставляться, и не от кого было защищаться. Почему я об этом пишу? Потому, что есть исследователи, которые достаточно обоснованно связывают воззрения многих авторов с особенностями их личности и жизненного пути [1]. Тем самым привносится, и с моей точки зрения, достаточно обоснованно, субъективный аспект в их размышления. Это очень отчётливо проявля- ется в концепциях Фрейда и Франкла. Стимулом к этим размышлениям у меня были самые разные - в детстве одни, в более зрелом возрасте - другие. Но всегда возникал вопрос, почему воспитатели, старшие по возрасту и положению, родители требуют, чтобы мы были добросовестными и честными, примерными и порядочными, исполнительными и аккуратными и т.д., понимая при этом, что это требование невыполнимо, поскольку все мы разные. Но эта «разность» почему-то всегда игнорируется, поскольку инстинктивно и/или сознательно мы понимаем, что есть определённые качества (добродетели), которые должны быть универсальными для всех людей, и именно эти моральные категории делают человека человеком. Но почему всегда эти требования-желания практически всеми нарушаются и не исполняются? Мы же будем в данной работе и в последующих статьях исходить из того, что не является универсальным для всех людей, будем искать то, что делает нас такими разными.

Ещё в школе, в классе 8-9-ом, я очень озадачил своего классного руководителя. Она преподавала нам физику, и, будучи очень занятым человеком, свои обязанности классного руководителя исполняла на уроке физики. И начинала она с того, что в очередной раз ругала класс за очередной побег с того или иного нелюбимого урока, за пропуски занятий, многочисленные «неуды» и «убогие «уды». Будучи старостой класса и примерным отличником, я как-то раз решился на противодействие классному руководителю и заметил: «Почему вы всегда ругаете нас, тех, кто всегда присутствует на уроке? Ведь те, к кому вы обращаетесь, всё равно вас не слышат! Их опять нет на уроке!».Учительница как-то вздрогнула, на секунду замолчала и в более мягких тонах продолжала нас воспитывать. И потом мне неоднократно приходилось слышать, да и сам делал замечания, даже «читал» нотации своим друзьям, коллегам, подчинённым: почему не успели? почему опоздали? почему не выполнили? почему были столь жестокими, агрессивными и т.д. И эти вопросы всегда были направлены одним и тем же лицам, а именно тем, кто успевал, не опаздывал, выполнял, был мягок и обходителен.

Но почему одни понимают, а другие нет? Почему одни успевают всё, а другие ничего? Почему 


\section{Психология и психотехника 12(87) • 2015}

одни терпеливые, устремлённые, конформные, а другие нет? Почему один «мягкий», податливый, жертвенный, другой - грубый, агрессивный, жестокий? Понять такую многогранную и противоречивую природу человека - наша цель.

Чтобы ответить на поставленные вопросы, следует дать ответы на другого рода вопросы: когда он (человек) начался как человек? что началось? почему и как началось? Как отмечает Б.Ф. Поршнев [2], в узко хронологическом аспекте, на вопрос когда он начался, есть три очевидных ответа, которые признаёт официальная наука, опираясь на достижения естественных наук и широкий фактический материал:

1. Люди и их специфическая история начались примерно полтора-два миллиона лет назад. Это было обусловлено появлением в конце третичной или начале четвертичной геологической эпохи видов прямоходящих высших приматов с головным мозгом поначалу ещё эволюционно более близким к антропоиду, чем к современному человеку, но с рукой, способной производить предельно элементарные орудия, свидетельствующие об основном комплексе человеческих социально-духовных качеств.

2. Люди - это вид Ноmo Sapiens, сформировавшийся 40-35 тыс. лет тому назад, а окончательно 25-20 тыс. лет назад, и только такова максимальная длительность человеческой истории; предшествовавшие полтора-два миллиона лет развития предковых форм могут быть полностью интерпретированы в понятиях естествознания. Переходный процесс становления человека занимает отрезок, начинающийся с поздних палеоантропов и включающий ранних неоантропов.

3. Обе вышеуказанные грани отмечают начало и конец («два скачка») процесса формирования человека из предшествовавшей животной формы.

Эти выводы были сделаны Б.Ф. Поршневым в 70-х гг. XX в. Но уже в конце прошлого века и начале нынешнего даже официальная наука на основе новых антропологических находок и палеогенетических исследований ДНК современного человека признала, что его предками были не только неандертальцы, но и другие, недавно обнаруженные виды человека: «флоресский» и «денисовский», которые жили одновременно в пространстве и во времени с Homo Sapiens. Современные генетические исследования митохондриальной и ядерной ДНК древних гоминид показали, что они внесли определённый вклад в происхождение вида Homo Sapiens, а сами оказались тупиковой ветвью эволюции. Расшифровка генома неандертальца, денисовского и флореского предков показали, что он (геном) на несколько процентов (1-4\%) совпадает с геномом современного человека, что уже достаточно, что- бы подтвердить факт скрещивания ранних людей современного типа с другими видами. И сегодня современный человек биологически представлен одним видом - Homo Sapiens. Психологически он проявляет себя достаточно разной, порой очень противоречивой особью. Предполагается, что след предков заметен в психике человека, который является результатом скрещивания нескольких «прародителей». Об этом мы писали в нашей статье «0 природе человека: происхождение человека в свете новых антропологических находок» [3]. Мы исходим из того, что природа человека неоднородна. При этом я имею в виду не только его биологическую природу, но и психическую (духовную и душевную). Эволюция живой природы подготовила феномен человека и сама включилась в процесс развития человеческой жизни. Динамический системный подход позволяет представить эволюцию человека в аспекте его психического развития, который представляется как непрерывный и взаимообусловленный процесс самоорганизации. Предполагается, что поведение и развитие человека есть результат функционирования сложных систем, которые включают психологические, биологические и физиологические компоненты, в которых действуют взаимоотношения нелинейного характера. Современный человек - это конечный результат длинной эволюционной неоднородной цепочки [4]. И в рамках синэргетической парадигмы человека следует рассматривать как биопсихосоциодуховную сущность, что позволяет адекватно понимать и оценивать все его «матрицы» в эволюционном аспекте: разум, веру, духовность, социальность. Иными словами, его биогенетическую, психогенетическую, анимогенетическую и социогенетическую матрицы [5].

Кроме огромного фактического (вещественного) материала, на который опирается официальная наука, есть «материал» психологический, не вещественный, который исследуется не лопаткой археолога, а совершенно другими методами, поскольку этот «материал» находится в психике человека и его человекоподобных предков. Поэтому есть и 4-й ответ на эти вопросы: человекообразные обезьяны обладают в зачатке свойствами, например «исследовательским поведением», «орудийной деятельностью», которые позволяют противопоставить их вместе с людьми всему остальному животному царству, следовательно, перелом восходит к миоцену [2]. Нам же следует предположить, что этих свойств не были лишены и древние люди, предки современного человека. Именно «археологические раскопки» психики человека пласт за пластом дают нам возможность понять, кто есть человек и какова его природа. Об этом будет сказано в нашей следу- 


\section{Философия и психология}

ющей работе, где психику, как феномен, имеющий свою историю развития и становления, мы рассматриваем как феномен человека, как объект биологический, со своей историей развития и становления: психопатологические проявления мы рассматриваем как исторические артефакты, адекватные в актуальном времени и пространстве, однако приобретшие патологический характер в настоящее время.

Ещё И.П. Павлов говорил: «Я не отрицаю психологии как познания внутреннего мира человека. Тем менее я склонен отрицать что-нибудь из глубочайших влечений человеческого духа. Здесь и сейчас я только отстаиваю и утверждаю абсолютные, непререкаемые права естественнонаучной мысли всюду и до тех пор, где и покуда она может проявлять свою мощь. А кто знает, где кончается эта возможность!» [6]. И я уверен, был бы И.П. Павлов нашим современником, наряду, а может и вместо естествознания, он отметил бы синергетику. Продолжая цитировать Б.Ф. Поршнева [2], отметим, что автор весь материал в виде вещественных и невещественных знаний относительно становления человека, подразделил на три группы: а) морфология антропогенеза, б) экология, биоценология и этология антропогенеза, в) физиология высшей нервной деятельности и психология антропогенеза. Обобщая историю данного вопроса, отметим, что с научных позиций разрабатывались, в основном, вопросы морфологии антропогенеза и частично, - вторая группа вопросов (экология, биоценология и этология антропогенеза). Заметных успехов научная мысль достигла уже в наши дни - начало XXI в. Анализ этих работ и достижений представлен нами в нашей статье «О природе человека: происхождение человека в свете новых антропологических находок» [3]. Много нерешённых вопросов и проблем имеется с третьей группой. Когда излагались эти мысли, у исследователей не было достаточной смелости анализировать психологический материал, поскольку всё недоказуемое рассматривалось как мистическое, следовательно, не научное. (А может, была высокая критичность?) Однако уровень и глубина наших знаний в психологии и психиатрии сегодня позволяют нам переходить грань от актуального к историческому. Объём экспериментальных процессов, в которых наблюдаются необъяснимые явления природы, постоянно растёт. Многие явления, связанные с сознанием, особенно с мышлением и психикой, ни в совокупности, ни даже в отдельности не находят описания на строгом научном уровне. Это свидетельствует, по меньшей мере, о неполноте современной науки с точки зрения её понимания природы [7]. По поводу причин, связанных с трудностями понимания психики или проблем Тонкого (невидимого) Мира со стороны ортодоксальных учёных, Г.Н. Дульнев отмечает, что «дело в том, что традиционная наука базируется на измерениях переноса энергии, массы и импульса. А в Тонком Мире идут, в основном, лишь процессы информационного обмена. Приборы для регистрации ещё не созданы. Кроме того, в исследованиях Тонкого Мира нарушается священный принцип традиционной науки - необходимость повторяемости результатов эксперимента. Объясняется это влиянием психики. Вот эти причины - отсутствие надёжного инструментария, неустойчивость явлений и психические непознаваемые взаимодействия, создают мнение у стандартно мыслящих учёных об отсутствии здесь собственно предмета исследования» [цит. по: 7].

Следуя логике римского права Cui bone est? (кому это выгодно?), мы задаёмся вопросом «как это возникло?». Однако мы чётко представляем себе, что если каким-то образом можно найти палеоархеологические ископаемые, чудом сохранившиеся в глубине земных и неземных недр, то такие находки с точки зрения биологии и психологии являются нереальными. Но вопрос нам представляется решаемым. По крайней мере, нам представляется, как следует подходить к решению данного вопроса. Исходя из принципа развития, диалектики, развиваемого ещё с античных времён, можно предположить, что человек не всегда был таким, каким он есть сегодня. Принцип историзма, применяемый Б.Ф. Поршневым [2], приводит к тезису: на заре истории человек по своим психическим характеристикам был не только не сходен с современным человеком, но и представлял его противоположность. Это развитие имеет как биологические, так и социальные корни. Причём социальное в человеке не сводится к его биологии, но без сомнения, социальное в человеке выводится исключительно из его биологии. Научно обоснованный подход к данному вопросу требует исходить из того, что человек является всё же природным существом, хотя и связанным с «колоссальной цивилизацией» [8]. Животные задатки за годы эволюции не пошли на убыль, они по-прежнему сильны, и мы продолжаем свой род вполне биологическим путём. Следовательно, человек, как и высшие коллективные животные, «подчиняется» закону Crook-a [9; 10], согласно которому структура сообществ высших коллективных животных зависит от биопродуктивности среды: биопродуктивность минимальна в пустынных регионах, и максимальна в богатых пищевыми ресурсами районах. Поэтому у населяющих пустыни обезьян Theropithecus gelada лишние самцы изгоняются из стада как ненужные рты, а 


\section{Психология и психотехника 12(87) • 2015}

победившие самцы-лидеры обзаводятся гаремами. То же наблюдается у жителей (аутохтонов) пустынной Северной Африки и Аравии, древних евреев и арабов, у которых издавна имелись гаремные семьи. Пустынные регионы порождают у обезьян патрилинейность, а у людей - патриархат, что в обоих случаях одинаково означает господство сильного пола. В свете закона Crook-а объясняется возникновение широкого спектра кровнородственных отношений людей: от гаремной семьи у выходцев из Аравийской пустыни и Сахары с её минимальной биопродуктивностью до свободной любви (промискуитета) в благополучных странах. В этом коренятся и некоторые механизмы подсознательных комплексов у современных людей, в частности, эдипов комплекс. В стадах обезьян доминирующее положение самцов нередко передаётся по линии господствующей самки-матери, откуда возникает тяга к тесным связям с ней, т.е. к инцесту. При этом молодые самцы не прочь избавиться от лидирующих самцов старшего поколения, т.е. от своих отцов, чтобы занять их место в стадной иерархии. В результате у молодых обезьян складывается благоприятная почва для эдипова комплекса, который и достался современным людям. У нормальных людей этот комплекс тормозится воспитанием.

Для понимания нашей концепции развития психики мы обратились к понятию «эволюционно стабильная стратегия поведения» (ЭССП), которую развивали психобиологически ориентированные исследователи $[11 ; 12]$. Всё многообразие поведенческой активности живых существ, в том числе человека, эти исследователи сводили к следующим четырем типам ЭССП: агонистическое, кооперативное, альтруистическое и эгоистическое.

Агонистическое поведение. В качестве такового рассматривается любое поведение, которое связано с конфликтами [13]. Агонистическое поведение обостряет отношения между людьми, способствует установлению ненормальных, противоречивых межличностных отношений и приводит к взаимной деструкции конфликтующих сил. В ситуации конфликта агрессия направляется не только на противоборствующую сторону, но может переадресовываться также на себя. В таких случаях формируется аутоагрессивное, в том числе суицидальное поведение. Но есть ситуации, в которых агонистическое поведение может оказаться облигатным, если агрессия носит оборонительный характер (например, защита своей территории, жизни, имущества).

Полной противоположностью агонистического поведения является кооперативное поведение. Оно полностью основано на отсутствии и отрицании конфликта, проявляется взаимными уступками, ком- промиссами и направленно на объединение усилий к достижению целей с наименьшими потерями. Социобиологический смысл кооперативного поведения заключается в адекватном реальным экологическим условиям взаимном сохранении жизненных преимуществ. При реализации кооперативного поведения в человеческом сообществе парадоксальным образом может проявиться аутоагрессия. В частности, в среде подростков в виде демонстративно-ритуального поведения (например, кровное скрепление договора), в клановых сообществах, объединённых родством или преклонением перед неким идолом. В широком смысле потенциально гибельным (аутоагрессивным) ритуалом в рамках кооперативного поведения является довольно распространённое распитие спиртных напитков в ознаменование какой-либо успешной совместной акции, даты, события.

Альтруистическое поведение связано с готовностью и реализацией самопожертвования ради блага других лиц или всего сообщества. Такое поведение регулируется девизом «сгорая сам, свечу другим». Социобиологический смысл экологически детерминированных («северных») парасуицидов, о которых пишет O.A. Gilburd, заключается в маркировке ценой собственного здоровья неблагоприятной для пришлого населения геоклиматической зоны. Парасуицидент тем самым сигнализирует своим поведением остальным мигрантам, что «здесь жить нельзя» [14]. Кстати, специальное эпидемиологическое исследование показало, что парасуицидальная активность у этнически русских на Севере достоверно выше, нежели в других, в том числе славянских, субпопуляциях [15].

Эгоистическое поведение рассматривается как полная противоположность альтруистическому поведению. Поведение связано с односторонним накоплением жизненных преимуществ и направлено на максимальное повышение уровня собственной приспособленности. Иначе говоря, это - «поведение выживания». Это ещё один важный момент, поскольку во взглядах на эгоистическое поведение существует явный дефинитивный «разброд». Психологи понимают эгоизм как частное проявление индивидуализма, определяющее центрированные на собственной персоне эмоциональный фон, образ мыслей и поведение конкретного лица. В рамках эгоистического поведения «допускается» возможность «эгоистического самоубийства» [16; 17]. С позиций социобиологического подхода это поведение - абсолютный нонсенс, так как самоубийство не может быть реализовано в рамках поведения выживания.

Таким образом, эволюция человека выработала, с точки зрения психобиологии, четыре основных «эволюционно стабильных стратегий по- 
ведения» [12]. Любые отклонения от этих форм поведения должны рассматриваться как аномальные. Более того, в рамках этих нормальных стратегий поведения допускаются те или иные отклонения. Понимание филогенеза аномального поведения людей, с нашей точки зрения, поможет понять природу самого человека и природу его психики. При этом мы исходим из того, что суть любого человеческого феномена проявляется в его крайностях. В данном случае в психозах.

Эволюционная гипотеза исходит из того, что для выработки адекватной биологической модели психоза следует искать типологические схожести психозов и соответствующих адаптивных реакций у животных, которые могут проявляться под воздействием стресса в естественных условиях. Психоз, как отмечают некоторые исследователи, можно рассматривать как «проявление чрезвычайно низкого порога соответствующей реакции у некоторых индивидуумов» [18; 19]. A.H. Esser, R.D. Deutsch [20], coпоставляя концепции эволюции и диссолюции, негативной и позитивной симптоматики, по Jackson, показали, что эволюционная концепция соответствует этологической, а психодинамическая - этолого-физиологической моделям. Типологические соответствия этологических моделей у приматов позволили установить соответствие поведения при депрессиях, неврозах, кататонии моделям «искусственной матери», депривации [21; 22; 23; 24; 25]. Оказалось, что в моделях не только менялась структура поведения (агонистического, сексуального, коммуникативного), но и нарушались типологические особенности практически всех систем, в частности территориальной. Были сделаны попытки выделить биологические основы поведения при неврозах и психопатиях на основании деструкции территориальности и доминирования, при подростковых реакциях - на основании искажения «социального облегчения», имитативности и группирования. Благодаря большей объективности в констатации поведения, как отмечает Л.В. Крушинский, удалось связать комплексы и проявления как нормального, так и аномального поведения с генетикой поведения [26; 27]. Переход от этологического анализа к семейному, в частности в модели мать-ребёнок [28] к групповому, основан на концепции альтруизма и реципрокного альтруизма; под последним понимается обмен альтруистическими актами [29]. W.D. Hamilton [30] показал эволюционную роль альтруизма. На основании описания математических моделей группового отбора он пришёл к выводу, что альтруизм сформировался в процессе естественного отбора по поведенческим признакам как признак, благодаря которому увеличивается вклад генов в генофонд популяции путём повышения совокупной приспособленности коадаптированной группы животных. Подобная идея развивается и Н.В. Клягиным [8]. Эту гипотезу Hamilton-a E.O. Wilson распространил на групповые и социальные отношения человека [31]. Социальное поведение (отношение) E.0. Wilson считает аналогом группового и общественного поведения животных, оно генетически детерминировано и является точкой приложения естественного отбора, связано с репродуктивностью, биологическими корнями морали и нравственности. То есть, по автору общественное поведение имеет в основе биологическую природу. Ценности, фиксированные в культуре, тоже имеют биологическую основу. Социобиология переносит энтомологические данные прямо на человеческое общество [32], в котором развитие культуры рассматривается с позиции формально-генетических транскрипций «культур-генов». Конечно, не следует абсолютизировать роль естественного отбора в современной эволюции человека в связи со сложной социальной и культурной средой, созданной самим человеком, развивающейся по своим собственным законам, но и не учитывать и не исходить из этого так же и столь же неэффективно [33]. И в этом нам помогает такая ветвь психиатрической науки, как психопатология. E.O. Wilson показал аналогии в моделях животного и человеческого поведения [31]. В противовес генетическому детерминизму некоторые этологи создают новую альтернативу, выдвигая положение о несоответствии адаптивных возможностей современного человека им же созданной среде. Так, N. Tinbergen [34] объясняет увеличение числа неврозов и сердечнососудистой патологии нарастанием дезадаптации человека и призывает к «раннему, более простому образу жизни». Напрашивается вывод о целесообразности возврата в прошлое, к пещерной жизни, к первобытному обществу. Ну а если рост числа неврозов и вообще психических отклонений никак не связан, по крайней мере, не однозначно связан с нарастанием дезадаптации человека в современных условиях, а является результатом определённых «поломок» в системе и проявлением ранних, архаических механизмов адаптации? Или может быть имеет место анимализация одних и антропоморфизация других?

E.O. Wilson [31] внедрил биологическую компоненту в социальное поведение человека и воссоединил две диаметрально противоположные тенденции развития самооценки личности: с одной стороны - Homo Sapiens как продукт эволюции органического мира, а с другой - человек, созданный по образу и подобию бога, и являющийся «царём» природы. Естественно, эти идеи, с одной стороны, 


\section{Психология и психотехника 12(87) • 2015}

были отвергнуты, поскольку, как отмечает П. Тюйе, «человеческий снобизм не может согласиться с тем, что он такая же тварь, как и другие», с другой - приняв, что является, чуть ли не богом, попытался вмешаться в его дела вплоть до регулирования рождаемости [35]. И, естественно, что возникает вопрос о том, какова же природа человека? Что в нем больше - животного или человеческого начала? Какова степень сублимации общественным сознанием биологических принципов поведения?

Долгие годы, начиная с исследований Ч. Дарвина, развивалась идея, что человек произошёл от обезьяны. Но сегодня, на основе молекулярно-генетических данных [36; 37], она оспаривается: предполагается, что предком была не обезьяна, а человекоподобный предок (гоминид), отделившийся от узконосых обезьян в начале миоцена (22 22 млн. лет назад). Однако эти данные не исключают животную природу человека. Но развитие биологической науки, в частности, генетики и этологии, выявило совершенно неожиданную картину, особенно для тех, кто подчёркивал именно социальную природу человека. Оказалось, что многие, казалось бы, такие сугубо человеческие качества, как альтруизм, нравственность, этические нормы, чувство справедливости выявляются и у животных. Причём, не только у обезьян - наших ближайших родственников. То есть, получается, что в каждом человеке есть немного животного, и в каждом животном есть немного человека. Речь идёт о антропоморфизации животных и анимализации человека [29; 38; 39]. Было показано, что социальное поведение человека опосредовано его биологией, которое, согласно E.O.Wilson [40], складывается из трёх программ: 1) закрытая генетическая программа; 2) открытая поведенческая программа и 3) внешняя программа, ограничивающая поведение.

Закрытая генетическая программа у человека реализуется через его инстинкты. Точно так же, как и у животных в зависимости от степени дифференциации нервной системы. А природа этой программы - одна, единая. То есть, социальная природа человека имеет биологические корни.

Открытая поведенческая программа определяется взаимодействием наиболее существенных биологических и экологических характеристик [41]. Многие поведенческие характеристики человека предопределены его морфологией, которая в процессе адаптации в изменяющихся условиях внешней среды формируется в соответствии с общебиологическими законами (такими, как законы Ф. Мюллера, Э. Геккеля, Ч. Дарвина, Ю. Либиха, Дж. Алена, К. Бергмана и др.). Открытые системы поведения определяют: 1) избегание неприятностей; 2) обе- спечение выживания максимального числа особей популяции и 3) воспроизведение генофонда [42]. В процессе реализации открытых программ, например, в процессе воспроизведения генофонда популяции, человек проявляет такие отклоняющиеся формы поведения, которые, на первый взгляд, свойственны исключительно человеку. Однако, как свидетельствуют исследования такие явления, как промискуитет и адюльтер проявляются не только у человека, но и у животных, тем самым обнаруживая определённую эволюционную природу. Так, среди человекообразных обезьян описаны самые разнообразные типы структуры общества (своего рода, семьи). Среди них, например, «семьи» горилл с разновозрастными самцами (место самца в иерархии определяется его возрастом), истинно многосамцовые «семьи» шимпанзе, в которых отмечается сосуществование нескольких половозрелых самцов. В литературе описаны случаи, не имеющие отношение к приматам. Так, Е.П. Гуськов [43] приводит пример из семейства пернатых - голубой сиалии, который демонстрирует реальность принципа сублимации биологически детерминированных основ поведения гуманитарными установками. Эти птицы относятся к социально моногамным птицам. Со времени создания гнезда партнёры держатся вместе, причём самец не отходит от самки. Появление посторонних самцов, не имеющих гнезда и территории, около брачной пары вызывает агрессивную реакцию самца-хозяина, выгоняющего «гостей» за границы территории. При этом у самца-резидента возрастает возможность адюльтера с самками, занимающими гнезда на соседних территориях. «Измена» самок своему партнёру ведёт к генетической полигинии и скрытому «альтруизму» обманутых самцов, вынужденно выкармливающих чужих птенцов. Целесообразное гнездовое поведение самца, с одной стороны, лишает его возможности адюльтера, с другой - препятствует оплодотворению самки «чужими» самцами [44]. Таким образом, сугубо человеческие моральные (библейские) заповеди «не возжелай жены ближнего», «не прелюбодействуй» проявляются у животных, и контролируется ими естественным отбором.

Другой пример относительно морально-этических категорий. S.F. Brosnan et al. [45], обобщая результаты своей работы с капуцинами, говорят об очень неожиданной проблеме. Обезьянки получали определённое задание, за выполнение которого получали «сладкое» вознаграждение. Для обезьян задачи были одинаковые, однако, капуцины не всегда получали то же самое количество еды. Если обезьянки замечали обман или подлог, то есть, если они замечали, что их «коллега» за ту же работу по- 


\section{Философия и психология}

лучала больше или более привлекательное вознаграждение, они отказывались получать приз меньшей ценности, и просто очень злились. Обезьяны выкидывали «унизительную подачку» и обиженно смотрели на своих хозяев. Авторы считают, что подобное поведение доказывает тот факт, что человек - отнюдь не единственный представитель животного мира, которому присуще понятие о справедливости. Обезьяны также имеют представление о своих обезьяньих правах и готовы бороться за них. Согласно теориям социологии, чувство справедливости лежит в основе успешной кооперации в человеческом обществе. Существуют гипотезы о том, что человек приобрёл чувство справедливости в процессе эволюции. Однако есть и версии, утверждающие, что быть справедливым человек учится, и это благородное чувство является не врождённым, а приобретённым. Поведение капуцинов говорит в пользу теории о врождённой природе чувства справедливости у человека. Таким образом, исследование на обезьянах открывает совершенно новые перспективы в области социологии. Категория нравственности у человека имеет древние корни и внушительные биологические предпосылки [8]. У высших животных поведение распадается на эгоистическую и альтруистическую составляющие. Эгоистическое поведение шлифуется под влиянием индивидуального естественного отбора, а альтруистическое своим происхождением обязано групповому [46; 47; 48], который побуждает организмы, располагающие общим генотипом, самоотверженно помогать друг другу, так что кажется, будто они заряжены неким геном альтруизма. Независимо от степени дифференциации нервной системы и характера разума (индивидуальный или коллективный) животные способны ради своей родни на большие жертвы. Они готовы воздерживаться от размножения (термиты, муравьи, пчёлы, осы, шмели; некоторые птенцовые птицы; млекопитающие вроде сурикатов или гиен), воспитывать чужое, но родственное потомство, защищать его и родню, не щадя жизни, и, разумеется, оказывать различные услуги [8].

Первые проявления альтруизма, зачатков нравственности у наших предков были обнаружены у самки Homo ergaster в Кении свыше 1,5 млн. лет назад [49]. Когда производительность труда у предков человека, как пишет Н.В. Клягин [8], стала нарастать, появилась необходимость в непроизводственном общении. Альтруистическое поведение тут же вошло в оборот и стало раздуваться пропорционально объёму праздного времени. Оно было построено на самоотверженности одних индивидов по отношению к другим. Потребность наших предков всё шире и шире применять эту способность (по мере подъёма производительности труда и развития свободного времени) привела к дифференциации проявлений самоотверженности. Как отмечалось, её элементарная, животная форма сводится к поддержанию и защите жизни и здоровья патронируемой родни, хотя порой дело доходит до содействия неродственным особям и даже представителям других видов, что отмечено у дельфинов, бегемотов, волков и др. Праздных предков человека такая узость устраивала всё меньше. Первым делом они принялись жертвовать в пользу собратьев не только наличными, но и будущими интересами, существующими лишь «в проекте». Это привело к запрету на ложь в отношениях с другими индивидами [8]. Животные нравы, подпитанные естественным отбором, требуют предпочтительного положения для выдающихся экземпляров, что ведёт к определённой иерархии, обычной у коллективных животных. Иерархичность привела к созданию конкретной системы норм, включающая самоотверженность, честность, равноправие и совесть. Она стала основой нравственного сознания.

Расширяясь, этическая сфера породила ещё две области духовной жизни: поведенческий этикет и правовые нормы. Не имея интеллектуальной, религиозной, нравственной или эстетической нагрузки, этикет выдерживается подобно этическим нормам, а оценивается скорее эстетически в понятиях приличного (красивого) и неприличного (некрасивого) поведения. Архетипы приличного поведения наших предков уходят в доисторические времена, а сегодня, судя по повадкам родственных нам шимпанзе и горилл, отмечаются и у них. Так, шимпанзе умеют пользоваться листьями как салфетками (столовыми и в качестве туалетной бумаги), заедают мясную пищу (например, кусочки мозга) листьями (подобно тому, как мы едим жаркое с гарниром), приветствуют друг друга наклоном головы (мы тоже при этом кланяемся) или даже припадают телом к земле (как делают люди перед лицом Бога или монарха), приветственно протягивают руку для рукопожатия, обнимаются, целуются (чмокаются, как женщины или политические лидеры при встречах), уважительно касаются головы рукой (мы снимаем шляпу или козыряем, если носим форму), самцы ободряюще треплют самок и детёнышей по подбородку (что делают и радушные мужчины) [50].

Таким образом, открытая поведенческая программа реализуется взаимодействием биологического и экологического факторов развития природы и человека.

Внешняя поведенческая программа, то есть свод правил и законов поведения индивида в человеческом обществе, в основе своей имеет биологи- 


\section{Психология и психотехника 12(87) • 2015}

ческую природу, она ограничивает поведение человека, так как задача, которую ставит перед собой социальная группа любого уровня - это выработка лучшей стратегии эволюционной устойчивости. При этом человеческое общество несколько меняет биологические акценты. Если альтруистическое поведение у животных, как правило, связано с реализацией возможности особи повысить «результирующую приспособляемость» и иметь больший репродуктивный успех [29], то человек предпринимает всё, чтобы изолировать людей с аберрантным для данной среды, (популяции, общества) поведением с целью исключения их из репродуктивного процесса - «плохие» люди не должны воспроизводиться. Изгнание из стаи (что наблюдается у стадных животных), из племени (практикуемое примитивными племенами), пожизненное заключение и казни в высокоразвитых обществах, организованных в государственные системы, преследуют одну сугубо биологическую цель - препятствовать распространению генов аберрантного поведения в обществе. Человек на современном этапе своего развития утратил ряд биологических механизмов регулирования оптимальной генетической структуры популяции. На их место пришли социальные механизмы - институты, выполняющие запретительные, карательные функции в виде моральных норм, законов, уголовного кодекса. Иными словами иерархически более старый механизм (или пласт) уступил место более новому механизму, но, при этом, он сохранился в «неактивном состоянии».

Maynard Smith [51] считает, что распространение в популяции родственных генов определяет степень и характер альтруистического поведения. W.D. Hamilton [38] показал, что кооперирование и альтруистическое поведение чаще можно встретить при взаимодействии родственных между собой особей. Точно так же, как и у человека. В литературе нет фактов патологической агрессии у животных против кровных родственников, хотя в принципе их исключить нельзя. Но каждый из нас может привести не один факт агрессии против себе подобных и даже достаточно близких, очевидцем которого был сам. Такая агрессия в человеческой популяции появилась, скорее всего, на ранних этапах становления общества. Однако, как социально неэффективная и вредная, такая модель поведения была осуждена и не воспринята.

Таким образом, внешняя поведенческая программа есть сугубо человеческое явление, направленное на выработку наилучшей стратегии эволюционной устойчивости. Но всё же она также имеет биологическую природу, но человеческое ядро меняет биологические акценты.
Существуют и другие модели поведения, свидетельствующие об анимализации человека и антропоморфизации животных. Среди них так называемое «право первой брачной ночи», принадлежащее в некоторых примитивных культурах (а возможно и всем древним людям) вожаку, предводителю, шаману. У животных она проявляется и регулируется правом альфа-самца. Это из ряда эволюционно оправданных исключений, хотя мораль и нравственность против подобного поведения.

В любой социальной группе доминирующей становится особь, обладающая способностью к долговременному прогнозу. Способность к длительному прогнозу не характерна для человека, поскольку связана с особенностями аналитического мышления, но она существует у животных в форме преадаптивного поведения. Однако прогнозирование существует уже на базе врождённых инстинктов: птицы строят гнезда задолго до начала откладки яиц, грызуны создают запасы до наступления холодов. У социально организованных животных с длительным ювенильным периодом воспитание и обучение создают основу будущего прогностического поведения. Животное прогнозирует своё поведение, предугадывая стихийное бедствие, например, землетрясение, анализируя изменение сигналов из окружающей среды. На уровне индивидуальных инстинктов нет разницы в поведении матерей животных и человека, жертвующих собой ради спасения потомства. На уровне социальных групп у животных защита вожаком стада от нападения хищников, выглядит более осознанной, так как вожак выделен из популяции не только потому, что он обладатель доминирующего генотипа, но и как наиболее вероятная жертва.

Другой важный симптом - постоянная внутривидовая война. Законы дикой природы допускают только убийство особей другого вида, но строго запрещает его внутри самого вида. И за редким исключением, которые мы наблюдаем среди крыс и некоторых насекомых, ни одно животное в природе, даже хищное, не «добивает» своего побеждённого сородича и даёт ему возможность уйти. Один лишь человек постоянно нарушает этот закон природы [52]. Однако, если не отвлекаться от фактов, истоки внутривидовых конфликтов, регулярно заканчивающихся гибелью какой-то части особей, возникли задолго до появления человека. Сложность внутривидовых отношений на любом уровне организации также контролируется генетической базой, определяющей поведение, целесообразность которого не всегда ясна исследователям.

Сходство поведенческих актов животных и ритуального поведения человека описано многи- 


\section{Философия и психология}

ми биологами. В частности, Л.В. Крушинский [27] отмечает сложную конструктивную деятельность животных. Птицы Австралии строят беседки в сезон брачных игр, которые украшают перьями и раковинами, самцы некоторых видов даже разрисовывают стены «кисточками» из листьев, используя сок давленых ягод. Однако биологическая основа ритуального поведения человека и животных различна. Вероятно, культура охотников и земледельцев возникла на различной генетической базе. Внешние атрибуты реализованной в культуре деятельности охотников первобытных племён более разнообразны, т.к. их способ существования подвержен мощным стрессорным воздействиям в отличие от собирателей и земледельцев. Пещерная живопись родилась как сублимация убийства, необходимого для выживания племени, явилась ритуальным действием, подобно игре хищника с жертвой. Культура, как институт эмоциональной настройки, стремится модифицировать стресс, связанный с актом убийства. Сегодня это находит отражение в великолепии украшений оружия, которые должны сублимировать в нашем восприятии орудия убийства в произведение искусства [43].

Заключение. «Чисто» человеческих поведенческих актов, не имеющих истоков в биологической природе предков Homo Sapiens, вероятно, не существует, так что психические обнаружения, социальные и моральные нормы и принципы, законы, регулирующие общественную жизнь в своём глубинном значении, являются диктатом этой самой природы. Более того, не только природы биологической, но и физической (косной). Мы не будем в деталях рассматривать и анализировать весь процесс эволюции неживой и живой природы, поскольку не это является нашей задачей. И более того, эти процессы подробно представлены во многих работах, в частности в труде Н.В. Клягина [8], на которого мы неоднократно ссылались в нашей работе. Наша планета немолода - возраст её достигает 4,55 млрд. лет [53], а возраст Солнечной системы - 4,566 \pm 0,002 млрд. лет [54]. Земной биогенез пока непостижим [55]. Возможно, жизнь принесена на Землю с другой планеты посредством комет, астероидов и метеоритов [56]. По крайней мере, сегодня известно, что паракодоновый (то есть, исходный) генетический код изученных организмов старше классического [57], что позволяет нам предположить, что исходный код сложился вне Земли и, оказавшись на нашей планете, стал адаптироваться в новых условиях. Вектор физической (геологической, химической, климатической, экологической и т.д.) эволюции планеты [58; 59] способствовал возникновению жизни, первые ископаемые следы которых появляются 3,85 млрд. лет назад [60]. За эти годы под влиянием климатических, экологических факторов имело место приспособление геномов (по крайней мере, части из них) к этим условиям, то есть имел место естественный отбор. Геномы находились в состоянии постоянного мутагенеза, что позволял им с успехом противостоять изменчивой среде. Как считает Ш. Ауэрбах [61], мутагенез не является случайным процессом и имеет несколько направлений (или типов): гиперморфные (мутация увеличивает проявление признака), гипоморфные (проявление признака уменьшается), антиморфные (признак уничтожается вообще) и неоморфные (признак дополняется). То есть, мутагенез является количественным процессом, создающим новое качество [62; 63; 64]. Выжили те организмы, которые неукоснительно следовали описанному способу количественного мутагенеза. Сохраняя позитив, что позволял им предугадывать очередной экологический катаклизм, они заново приспосабливались в теперь уже новых условиях и сохраняли жизнь. Другая часть так же гарантированно вымирала. В этой системе представлений укладывается и современный человек в своем фило- и онтогенезе, становится понятным происхождение его как биологического и психологического объекта. Современный человек сохраняет в себе все генотипические и фенотипические характеристики и свойства, когда-либо проявленные его предковыми формами, причём не всегда наиболее целесообразные и выгодные. Причём старый признак (качество, свойство) не исчезал бесследно, не уничтожался, а сохранялся как архаический феномен, и вместо него начинал действовать новый признак, который, в свою очередь, на очередном цикле развития, утрачивал свой адаптативный характер, и уступал место новому феномену. При этом, как справедливо замечает Н.В. Клягин [8], в этом эволюционном процессе решающую роль играют взаимоотношения процессов неотении и акселерации. В силу неотении у приматов и у доисторических людей затормозились процессы эволюционного развития на уровне эволюции генов, хромосом, геномов. В результате геном людей сохранил «застойный облик», то есть древние гены, которые при внешних воздействиях могут вызвать так называемые «обратные мутации» (т.е. изменения, восстанавливающие предковый облик отдельных генов) [62]. На уровне физиологии и анатомии могут появиться обильные кожные железы земноводных, даже свойственная их ранним представителям шестипалость. Можно отметить и появле- 


\section{Психология и психотехника 12(87) • 2015}

ние «третьего века» у некоторых людей, а также копчика. В силу этого процесса приматы получили шанс успешно адаптироваться в изменяющихся условиях среды. Этот феномен С. Оно обозначил как «наследование примитивными Земли» [62], что обещало нашим предкам перспективную судьбу. Указанные эволюционные обстоятельства делали развитие приматов запутанным. Это подтверждается, в частности тем, что до сих пор чётко не определены наши предки [65; 66], а палеогенетические исследования обнаруженных останков предков людей показали, что современный человек является носителем генов не только кроманьенцев, но и неандертальцев, алтайского и флоресского человека [3]. Развитие человека происходило в «единстве и борьбе» двух противоположных процессов - неотении и акселерации. Неотения проявляется в возникновении простых, примитивных, инфантильных и даже эмбриональных признаков, что приводит к замедлению индивидуального развития организма. Именно способность сохранять во взрослом состоянии детские и эмбриональные особенности способствовала возникновению современного человека [8]. На протяжении своей эволюции гоминины (наши предки) всё заметнее уподоблялись эмбрионам, что выразилось у них в грацилизации, т.е. в утончении костей скелета и приобретении изящества. На современном этапе развития человека это явление усиливается благодаря всё большему «одомашниванию», цивилизации человека, что изнеживает и инфантилизирует людей [67].

Процесс акселерации, начавшийся в межледниковую эпоху примерно 125 тыс. лет назад у классического неандертальца, привёл к тому, что он стал крупнее (на 30\%) современного среднего человека [68], что отражало ускорение онтогенеза у неандертальца [69]. Эта идея находит своё подтверждение в современных исследованиях, свидетельствующих, что у млекопитающих в суровых условиях активируется обмен веществ [70], что приводит к более быстрому развитию организма. Каждый новый этап в развитии человека сохранял прежние «достижения» и создавал условия для появления новых качеств, способствующих адаптации в условиях климатических и геологических катастроф. Неторопливые, неотеничные предки человека вели себя сдержанно и спокойно, пользовались традиционными достижениями предшествующих эпох, не стремясь их совершенствовать, и, образно говоря, только размножались. Увеличение их числа на определённой территории, в условиях ограниченного количества пищи, приводил к демографическому взрыву. Популяция претерпевала акселерацию, и акселерированные предки производили в силу инфантильности технологическую и культурную революции, То есть, прогрессивные акселераты в силу детской исторической наивности работали во благо исторически медлительным, т.е. примитивным, неотеникам. В итоге примитивные существа наследовали социум, обновленный по-детски бесхитростными акселератами.

Поведение человека с доисторических времён и до настоящего времени обусловлено его биологической (инстинктивной) природой, что подтверждается наличием прототипов практически всех форм поведения у животных, и не только у высших. Только появление разума как сугубо социального феномена, а не биологического, как это можно представить исходя из старых парадигм, определило человека как существо социальное. Как отмечает Н.В. Клягин [8], разум человеческого типа биологически не выгоден. В противном случае он бы появился у других двуногих животных, имевших хватательные верхние конечности с отстоящим «большим» пальцем, пригодным для развития точного захвата (например, у динозавров). Разум выгоден лишь человеческому социуму Человек, как и все живые организмы на нашей планете, живёт и развивается по правилам природы, которая ничего не теряет, а на основе имеющегося создаёт новое. Если разум оказывается биологически не выгодным феноменом, значит существует другая необходимость его появления и существования. Это, скорее всего, - Вселенская необходимость и целесообразность. Биологически все живые организмы «построены» из одних и тех же «кирпичиков» - углерода, водорода, азота, кислорода, фосфора и серы, из которых строятся аминокислиты, протеины, вода и т.д. На их основе возникли ДНК и РНК, положившие начало генам и хромосомам, то есть субстратам и механизмам сохраняющим и передающим информацию в фило- и онтогенезе. Биология и генетика, и тем более молекулярная биология и генетика, достигли огромных успехов в раскрытии глубинных тайн жизни, но в тайны материального фундамента психики остались нераскрытыми [71]. Нуклеиновые кислоты имеют одинаковый химический состав как в живом, так и в умершем состоянии, они характерны как для примитивных, так и для высокоорганизованных организмов. И здесь мы опять возвращаемся к Тонкому миру, информационному полю, которая по-разному соотносится с живыми организмами. Существует специфика собственно психических процессов на другом уровне, которую и пытаемся выявить. 


\section{Философия и психология}

\section{Список литературы:}

1. Хьелл Л., Зиглер Д. Теории личности: основные положения, исследования и применение / Пер. С. Меленевской и Д. Викторовой. 2-е изд., испр. СПб.: Питер, 2001. 606 с.

2. Поршнев Б.Ф. 0 начале человеческой истории (Проблемы палеопсихологии). М.: Мысль, 1974. 487 с.

3. Сукиасян С.Г. О природе человека: происхождение человека в свете новых антропологических находок // Концепт. 2015. № 12 (декабрь). ART 15408. URL: http://e-koncept.ru/2015/15408.htm.

4. Сукиасян С. Г. Суть и природа человека: эволюция homo sapiens // Концепт. 2015. № 11 (ноябрь). ART 15376. URL: http:// e-koncept.ru/2015/15376.htm.

5. Сидоров П.И. Системный синтез ментальной медицины // Экология человека. 2013. № 10. С. 37-48.

6. Павлов И.П. Полное собрание трудов. М.-Л.: Изд-во АН СССР, 1949. Т. 3. С. 104.

7. Тихоплав Т.С., Тихоплав В.Ю. Физика веры. СПб.: ИД «ВЕСЬ», 2003. 256 с.

8. Клягин Н.В. Современная научная картина мира. М.: Логос, 2007. 263 с.

9. Crook J.H. The Socio-ecology of Primates // Social Behavior in Birds and Mammals. Essays on the Social Ethology of Animals and Man L. N.Y.: Academic Press Inc. (London) Ltd., 1970. P. 103-166.

10. Crook J.H. Social behavior and ethology // The Origin \& Evolution of Man: Readings in physical anthropology. N.Y.: T.Y. Crowell Co, Inc., 1973. P. 283-295.

11. Макфарленд Д. Поведение животных: психобиология, этология и эволюция. М.: Мир, 1988. 487 с.

12. Эрман Л., Парсонс П. Генетика поведения и эволюция. М.: Мир, 1984. 566 с.

13. Самохвалов В.П. История души и эволюция помешательства. Сургут: Северный Дом, 1994. 286 с.

14. Gilburd O.A. Myth about Jesus Christ and sociobiology of suicide behavior in Russian ethnos. Ethology and Evolution of Human Behavior: Intern. Conf. (Book of Abstracts). Simferopol, 1992. P. 19.

15. Гильбурд О.А. Социобиология суицидального поведения в русском этносе и внеэтнические корни потребности в самоубийстве // Acta Psychiatrica, Psychologica, Psychotherapeutica et Ethologica Tavrica. 1995. No 2(3). C. 60-75.

16. Бердяев Н.А. 0 самоубийстве (психологический этюд) // Психолог. журн. 1992. № 2. С. 90-94.

17. Дюркгейм Э. Самоубийство: социологический этюд. СПб., 1912. 498 с.

18. Колпаков В.Г., Рицнер М.С., Корнетов Н.А. и др. Генетические и эволюционные проблемы психиатрии / Отв. ред. А.С. Тимофеева; АН СССР. Сиб. отделение. Ин-т цитологии и генетики. Новосибирск: Наука; Сиб. отделение, 1985.255 с.

19. Короленко Ц.П., Колпаков В.Г. Соображения об эволюционно-биологическом аспекте проблемы эндогенныхпсихозов // Журн. невропатол. и психиатр. 1976. № 1. С. 134-141.

20. Esser A.H., Deutsch R.D. Private and interaction territory on psychiatric wards: Studies on verbal communication of spatial needs / Eds. by M.T. McGuire and L.A. Fairbanks. Ethological psychiatry: Psychopathology in the context of evolutionary biology. New York: Grune and Statton, 1977.

21. Harlow H.F. Total isolation: Effects on macaque monkey behavior // Science. 1965. No 148. P. 666.

22. Harlow H.F., Harlow M.K. Learning to love // Amer. Scient. 1966. No 54. P. 244-272.

23. Harlow H.F., Novak M.A. Psychopathological perspectives // Perspectives in Biology and Medicine. 1973. No 16(3). P. 461-478.

24. Harlow H.F., Suomi S.J. Induced depression in monkeys // Behavioral Biology. 1974. No 12. P. 273-296.

25. Harlow H.F., Suomi S.J. Production of depressive behavior in young monkeys // J. Autism. Childhood Schizophrenia. 1971 . No 1. P. 246-255.

26. Крушинский Л.В. Биологические основы рассудочной деятельности. М.: Изд-во МГУ, 1986. 270 с.

27. Крушинский Л.В. Эволюционно-генетические проблемы поведения животных и человека // Журн. невропатол. и психиат. 1982. № 82. С. 18-22.

28. Bowlby I. Human personality in an ethological light / Eds. by Serban G., Kling A. Animal models in human psychobiology. N.Y.: Pieman Press, 1976. P. 5-74.

29. Trivers R.L. The evolution of reciprocal altruism // Quart. rev. biology. N.Y., 1971. No 46(1). P. 35-57. (D0I:10.1086/406755)

30. Hamilton W.D. The evolution of altruistic behavior. // Amer. Naturalist. Chicago. 1963. No 97. P. 354-356.

31. Wilson E.O. Sociobiology: The new synthesis. Cambridge (Mass)-London, 1975. 697 p.

32. Lumsden Ch.J., Wilson E.O. Genes, mind and culture. The coevolutionary process. Cambridge: Harvard Univ. Press, 1981.417 p.

33. Уиттекер Р. Сообщества и экосистемы. М.: Прогресс, 1980. 328 с.

34. Tinbergen N. Ethology and stress diseases // Science. 1974. No 185. P. 20-27.

35. Тюйе П. Соблазны евгенизма // Генетика и наследственность: сборник статей. М.: Мир, 1987. С. $229-252$.

36. Jasny B.R., Hines P.J. Genome Prospecting // Science. 1999. Vol. 286. No 5439. P. 365, 443.

37. Wilson A.C, Sarich V.M. A molecular time scale for human evolution // Proceedings of the National Academy of Sciences of the USA. 1969. Vol. 63. No 4. P. 1088-1093.

38. Hamilton W.D. The genetically evolution of social behavior // J. Theor. Biol. 1964. No 7. P. 1-52.

39. Lorenz K. The functional limits of morality. Sociobiology debate: Readings on ethical sci. issues. N.Y., 1978. P. 67-75.

40. Wilson E.O. A consideration of the genetic foundation of human social behavior // Sociobiology: Beyond nature / nurture? 1980. P. 295-306.

41. Emben S.T. Ecological determinism and sociobiology // Sociobiology: Beyond nature / nurture? 1980. P. 331-370.

42. Смит М.Дж. Эволюция полового размножения. М., 1981. 272 с.

43. Гуськов Е.П. Биология, социология и принцип сублимации // Известия высших учебных заведений. Северо-Кавказский регион. 1994. Спецвыпуск. С. 18-24.

44. Benzer S. From gene to behavior // JAMA. 1971. No 218. P. 1015-1026.

45. Brosnan S.F., Waal F.B.M. Reply to «Inequity aversion in capuchins» // Nature. 2004. No 428. P. 140. 


\section{Психология и психотехника 12(87) • 2015}

46. Дьюсбери Д. Поведение животных: Сравнительные аспекты. М.: Мир, 1981. 480 с.

47. Эфроимсон В.П. Эволюционно-генетическое происхождение альтруистических эмоций // Научная мысль. Вестник Агентства печати «Новости» (АПН). М.: АПН, 1968. С. 27-42.

48. Griffin A.S., West S.A. Kin Discrimination and the Benefit of Helping in Cooperatively Breeding Vertebrates // Science. 2003. Vol. 302. No 5645. P. 634-636.

49. Бутовская М.Л., Файнберг Л.А. У истоков человеческого общества: Поведенческие аспекты эволюции человека. М.: Наука, 1993. 256 с.

50. ван Лавик-Гудолл Дж. В тени человека. М.: Мир, 1974. 207 с.

51. Smith J.M. The evolution of behavior // Sci. Amer. 1978. No 239. P. 176-191.

52. Кестлер А. Человек-ошибка эволюции // Время и мы: сб. М.-N.Y., 1990. C. 221-234.

53. Wilde S.A., Valley J.W., Peck W.H., Graham C.M. Evidence from detrital zircons for the existence of continental crust and oceans on the Earth 4.4 Gyr ago // Nature. 2001. Vol. 409. No 6817. P. 175-178.

54. Halliday A.N. Earth Science: In the beginning... // Nature. 2001. Vol. 409. No 6817. P. 144-145.

55. Scott A. Update on Genesis // New scientist. 1985. Vol. 106. No 1454. P. 30-33.

56. Delsemme A.H. An Argument for the Commentary Origin of the Biosphere // American Scientist. 2001. Vol. 89. No 5. P. 432-442.

57. Duve C. de. The second genetic code // Nature. 1988. Vol. 333. No 6169. P. 117-118.

58. Maber K.A., Stevenson D.J. Impact frustration of the origin of life // Nature. 1988. Vol. 331. No 6157. P. 612-614.

59. Mojzsis S.J., Harrison T.M., Pidgeon R.T. Oxygen-isotope evidence from ancient zircons for liquid water at the Earth's surface 4,300 Myr ago // Nature. 2001. Vol. 409. No 6817. P. 178-181.

60. Holland H.D. Evidence for Life on Earth More Than 3850 Million Years Ago // Science. 1997. Vol. 275. No 5296. P. 38-39.

61. Ауэрбах Ш. Проблемы мутагенеза. М.: Мир, 1978. 463 с.

62. Оно С. Генетические механизмы прогрессивной эволюции. М.: Мир, 1973. 227 с.

63. Lynch M., Conery J.S. The Evolutionary Fate and Consequences of Duplicate Genes // Science. 2000. Vol. 290. No 5494. P. $1151-1155$.

64. Lynch M., Conery J.S. The Origins of Genome Complexity // Science. 2003. Vol. 302. No 5649. P. 1401-1404.

65. Andrews P. Evolution and environment in the Hominoidea // Nature. 1992. Vol. 360. No 6405. P. 641-646.

66. Gebo D.L., MacLatchy L., Kibyo R. et al. A Hominoid Genus from the Early Miocene of Uganda // Science. 1997. Vol. 276. No 5311. P. 401-404.

67. Leach H.M. Human Domestication Reconsidered // Current Anthropology. 2003. Vol. 44. No 3. P. 349-368.

68. Kappelman J. They might be giants // Nature. 1997. Vol. 387. No 6629. P. 126-127.

69. Martin B., Harvey P.H. Human bodies of evidence // Nature. 1987. Vol. 330. No 6150. P. 697-698.

70. Diamond J.M. Quantitative design of life // Nature. 1993. Vol. 366. No 6454. P. 405-406.

71. Дубров А.П., Пушкин В.Н. Парапсихология и современное естествознание. М.: Соваминко, 1989. 280 с.

\section{References (transliteration):}

1. Kh'ell L., Zigler D. Teorii lichnosti: osnovnye polozheniya, issledovaniya i primenenie / Per. S. Melenevskoi i D. Viktorovoi. 2-e izd., ispr. SPb.: Piter, 2001. 606 s.

2. $\quad$ Porshnev B.F. 0 nachale chelovecheskoi istorii (Problemy paleopsikhologii). M.: Mysl', 1974. 487 s.

3. Sukiasyan S.G. O prirode cheloveka: proiskhozhdenie cheloveka v svete novykh antropologicheskikh nakhodok // Kontsept. 2015. № 12 (dekabr'). ART 15408. URL: http://e-koncept.ru/2015/15408.htm.

4. Sukiasyan S.G. Sut' i priroda cheloveka: evolyutsiya homo sapiens // Kontsept. 2015. № 11 (noyabr'). ART 15376. URL: http://ekoncept.ru/2015/15376.htm.

5. Sidorov P.I. Sistemnyi sintez mental'noi meditsiny // Ekologiya cheloveka. 2013. № 10. S. 37-48.

6. Pavlov I.P. Polnoe sobranie trudov. M.-L.: Izd-vo AN SSSR, 1949. T. 3. S. 104.

7. Tikhoplav T.S., Tikhoplav V.Yu. Fizika very. SPb.: ID «VES”», 2003. 256 s.

8. $\quad$ Klyagin N.V. Sovremennaya nauchnaya kartina mira. M.: Logos, 2007. 263 s.

9. Crook J.H. The Socio-ecology of Primates // Social Behavior in Birds and Mammals. Essays on the Social Ethology of Animals and Man L. N.Y.: Academic Press Inc. (London) Ltd., 1970. P. 103-166.

10. Crook J.H. Social behavior and ethology // The Origin \& Evolution of Man: Readings in physical anthropology. N.Y.: T.Y. Crowell Co, Inc., 1973. P. 283-295.

11. Makfarlend D. Povedenie zhivotnykh: psikhobiologiya, etologiya i evolyutsiya. M.: Mir, 1988. 487 s.

12. Erman L., Parsons P. Genetika povedeniya i evolyutsiya. M.: Mir, 1984. 566 s.

13. Samokhvalov V.P. Istoriya dushi i evolyutsiya pomeshatel'stva. Surgut: Severnyi Dom, 1994. $286 \mathrm{s.}$

14. Gilburd O.A. Myth about Jesus Christ and sociobiology of suicide behavior in Russian ethnos. Ethology and Evolution of Human Behavior: Intern. Conf. (Book of Abstracts). Simferopol, 1992. P. 19.

15. Gil'burd O.A. Sotsiobiologiya suitsidal'nogo povedeniya v russkom etnose i vneetnicheskie korni potrebnosti v samoubiistve // Acta Psychiatrica, Psychologica, Psychotherapeutica et Ethologica Tavrica. 1995. № 2(3). S. 60-75.

16. Berdyaev N.A. O samoubiistve (psikhologicheskii etyud) // Psikholog. zhurn. 1992. № 2. S. 90-94.

17. Dyurkgeim E. Samoubiistvo: sotsiologicheskii etyud. SPb., 1912. $498 \mathrm{~s}$.

18. Kolpakov V.G., Ritsner M.S., Kornetov N.A. i dr. Geneticheskie i evolyutsionnye problemy psikhiatrii / Otv. red. A.S. Timofeeva; AN SSSR. Sib. otdelenie. In-t tsitologii i genetiki. Novosibirsk: Nauka; Sib. otdelenie, 1985. 255 s.

19. Korolenko Ts.P., Kolpakov V.G. Soobrazheniya ob evolyutsionno-biologicheskom aspekte problemy endogennykh psikhozov // Zhurn. nevropatol. i psikhiatr. 1976. № 1. S. 134-141.

20. Esser A.H., Deutsch R.D. Private and interaction territory on psychiatric wards: Studies on verbal communication of spatial needs / Eds. by M.T. McGuire and L.A. Fairbanks. Ethological psychiatry: Psychopathology in the context of evolutionary biology. New York: Grune and Statton, 1977. 


\section{Философия и психология}

21. Harlow H.F. Total isolation: Effects on macaque monkey behavior // Science. 1965. No 148. P. 666.

22. Harlow H.F., Harlow M.K. Learning to love // Amer. Scient. 1966. No 54. P. 244-272.

23. Harlow H.F., Novak M.A. Psychopathological perspectives // Perspectives in Biology and Medicine. 1973. No 16(3). P. $461-478$.

24. Harlow H.F., Suomi S.J. Induced depression in monkeys // Behavioral Biology. 1974. No 12. P. 273-296.

25. Harlow H.F., Suomi S.J. Production of depressive behavior in young monkeys // J. Autism. Childhood Schizophrenia. 1971. No 1. P. 246-255.

26. Krushinskii L.V. Biologicheskie osnovy rassudochnoi deyatel'nosti. M.: Izd-vo MGU, 1986. 270 s.

27. Krushinskii L.V. Evolyutsionno-geneticheskie problemy povedeniya zhivotnykh i cheloveka // Zhurn. nevropatol. i psikhiat. 1982. № 82. S. 18-22.

28. Bowlby I. Human personality in an ethological light / Eds. by Serban G., Kling A. Animal models in human psychobiology. N.Y.: Pieman Press, 1976. P. 5-74.

29. Trivers R.L. The evolution of reciprocal altruism // Quart. rev. biology. N.Y., 1971. No 46(1). P. 35-57. (D0I:10.1086/406755)

30. Hamilton W.D. The evolution of altruistic behavior. // Amer. Naturalist. Chicago. 1963. No 97. P. 354-356.

31. Wilson E.O. Sociobiology: The new synthesis. Cambridge (Mass)-London, 1975. 697 p.

32. Lumsden Ch.J., Wilson E.O. Genes, mind and culture. The coevolutionary process. Cambridge: Harvard Univ. Press, 1981.417 p.

33. Uitteker R. Soobshchestva i ekosistemy. M.: Progress, 1980. 328 s.

34. Tinbergen N. Ethology and stress diseases // Science. 1974. No 185. P. 20-27.

35. Tyuie P. Soblazny evgenizma // Genetika i nasledstvennost': sbornik statei. M.: Mir, 1987. S. 229-252.

36. Jasny B.R., Hines P.J. Genome Prospecting // Science. 1999. Vol. 286. No 5439. P. 365, 443.

37. Wilson A.C, Sarich V.M. A molecular time scale for human evolution // Proceedings of the National Academy of Sciences of the USA. 1969. Vol. 63. No 4. P. 1088-1093.

38. Hamilton W.D. The genetically evolution of social behavior // J. Theor. Biol. 1964. No 7. P. 1-52.

39. Lorenz K. The functional limits of morality. Sociobiology debate: Readings on ethical sci. issues. N.Y., 1978. P. 67-75.

40. Wilson E.O. A consideration of the genetic foundation of human social behavior // Sociobiology: Beyond nature / nurture? 1980. P. 295-306.

41. Emben S.T. Ecological determinism and sociobiology // Sociobiology: Beyond nature / nurture? 1980. P. 331-370.

42. Smit M.Dzh. Evolyutsiya polovogo razmnozheniya. M., 1981. $272 \mathrm{s.}$

43. Gus'kov E.P. Biologiya, sotsiologiya i printsip sublimatsii // Izvestiya vysshikh uchebnykh zavedenii. Severo-Kavkazskii region. 1994. Spetsvypusk. S. 18-24.

44. Benzer S. From gene to behavior // JAMA. 1971. No 218. P. 1015-1026.

45. Brosnan S.F., Waal F.B.M. Reply to «Inequity aversion in capuchins» // Nature. 2004. No 428. P. 140.

46. D'yusberi D. Povedenie zhivotnykh: Sravnitel'nye aspekty. M.: Mir, 1981. $480 \mathrm{~s}$.

47. Efroimson V.P. Evolyutsionno-geneticheskoe proiskhozhdenie al'truisticheskikh emotsii // Nauchnaya mysl'. Vestnik Agentstva pechati «Novosti» (APN). M.: APN, 1968. S. 27-42.

48. Griffin A.S., West S.A. Kin Discrimination and the Benefit of Helping in Cooperatively Breeding Vertebrates // Science. 2003. Vol. 302. No 5645. P. 634-636.

49. Butovskaya M.L., Fainberg L.A. U istokov chelovecheskogo obshchestva: Povedencheskie aspekty evolyutsii cheloveka. M.: Nauka, 1993. $256 \mathrm{~s}$.

50. van Lavik-Gudoll Dzh. V teni cheloveka. M.: Mir, 1974. $207 \mathrm{s.}$

51. Smith J.M. The evolution of behavior // Sci. Amer. 1978. No 239. P. 176-191.

52. Kestler A. Chelovek-oshibka evolyutsii // Vremya i my: sb. M.-N.Y., 1990. S. 221-234.

53. Wilde S.A., Valley J.W., Peck W.H., Graham C.M. Evidence from detrital zircons for the existence of continental crust and oceans on the Earth 4.4 Gyr ago // Nature. 2001. Vol. 409. No 6817. P. 175-178.

54. Halliday A.N. Earth Science: In the beginning... // Nature. 2001. Vol. 409. No 6817. P. 144-145.

55. Scott A. Update on Genesis // New scientist. 1985. Vol. 106. No 1454. P. 30-33.

56. Delsemme A.H. An Argument for the Commentary Origin of the Biosphere // American Scientist. 2001. Vol. 89. No 5. P. $432-442$.

57. Duve C. de. The second genetic code // Nature. 1988. Vol. 333. No 6169. P. 117-118.

58. Maber K.A., Stevenson D.J. Impact frustration of the origin of life // Nature. 1988. Vol. 331. No 6157. P. $612-614$.

59. Mojzsis S.J., Harrison T.M., Pidgeon R.T. Oxygen-isotope evidence from ancient zircons for liquid water at the Earth's surface 4,300 Myr ago // Nature. 2001. Vol. 409. No 6817. P. 178-181.

60. Holland H.D. Evidence for Life on Earth More Than 3850 Million Years Ago // Science. 1997. Vol. 275. No 5296. P. 38-39.

61. Auerbakh Sh. Problemy mutageneza. M.: Mir, 1978. $463 \mathrm{s.}$

62. Ono S. Geneticheskie mekhanizmy progressivnoi evolyutsii. M.: Mir, 1973. $227 \mathrm{~s}$.

63. Lynch M., Conery J.S. The Evolutionary Fate and Consequences of Duplicate Genes // Science. 2000. Vol. 290. No 5494. P. 11511155.

64. Lynch M., Conery J.S. The Origins of Genome Complexity // Science. 2003. Vol. 302. No 5649. P. 1401-1404.

65. Andrews P. Evolution and environment in the Hominoidea // Nature. 1992. Vol. 360. No 6405. P. 641-646.

66. Gebo D.L., MacLatchy L., Kibyo R. et al. A Hominoid Genus from the Early Miocene of Uganda // Science. 1997. Vol. 276. No 5311. P. 401-404.

67. Leach H.M. Human Domestication Reconsidered // Current Anthropology. 2003. Vol. 44. No 3. P. 349-368.

68. Kappelman J. They might be giants // Nature. 1997. Vol. 387. No 6629. P. 126-127.

69. Martin B., Harvey P.H. Human bodies of evidence // Nature. 1987. Vol. 330. No 6150. P. 697-698.

70. Diamond J.M. Quantitative design of life // Nature. 1993. Vol. 366. No 6454. P. 405-406.

71. Dubrov A.P., Pushkin V.N. Parapsikhologiya i sovremennoe estestvoznanie. M.: Sovaminko, 1989. $280 \mathrm{~s}$. 